Syntax Fusion : Jurnal Nasional Indonesia

P-ISSN: $x x x x-x x x x$

e-ISSN : $x x x x-x x x x$

Vol. 1, No. 1, Oktober 2020

\title{
PESAN DAKWAH DALAM KISAH ABU NAWAS (Studi Analisis Semiotika Charles Sanders Peirce)
}

\section{Vina Rosalina}

\section{Sekolah Tinggi Agama Islam (STAIPI) Bandung}

Email: rosavina1298@gmail.com

\section{Abstrak}

Pesan dakwah merupakan salah satu unsur perantara dalam mentransformasikan nilai-nilai keIslaman pada masyarakat. Salah satu sumber pesan dakwah ialah karya sastra berupa kisah. Termasuk Kisah Abu Nawas terjemahan Nur Sutan Iskandar. Abu Nawas terkenal sebagai tokoh yang arif dan bijaksana serta mampu memecahkan berbagai persoalan dalam kehidupan dengan style humornya yang nyeleneh. Termasuk persoalan kehidupan di Indonesia, yaitu terjadinya penyimpangan akidah, kelalaian bersyari'ah dan kebobrokan akhlak.

Dalam penelitian ini, penulis menggunakan pendekatan kepustakaan dan kualitatif deskriptif dengan metode analisis isi (content analysis). Pengumpulan data menggunakan study library (menghimpun informasi yang relevan dengan topik atau masalah yang menjadi objek penelitian, informasi tersebut diperoleh dari buku-buku, karya ilmiah, ensiklopedia, internet dan sumber lainnya), observasi dan dokumentasi. Selanjutnya, data disaring dan disusun lagi, dipaparkan, diverifikasi dan dibuat kesimpulan.

Pesan dakwah dalam kisah Abu Nawas mengandung pesan akidah terdiri dari iman kepada Allah Swt. Syariah terdiri dari shalat dan kepengurusan jenazah. Adapun akhlak terdiri dari akhlak kepada Allah dan akhlak terhadap manusia. Penelitian ini diharapkan dapat menjadi bahan pertimbangan da'I dalam penyampaian pesan di kegiatan dakwahnya. Selain berdakwah di mimbar, bisa juga dengan kegiatan menganalisis suatu teks dalam kisah lalu dituangkan kembali maknanya dalam bentuk tulisan (Dakwah bil-Kitabah).

Berdasarkan penelitian yang telah dilakukan terhadap kisah Abu Nawas melalui analisis semiotika Charles Sanders Peirce disimpulkan bahwa pesan dakwah dalam kisah ini menyangkut tentang akidah, syariah dan akhlak.

Kata Kunci : Pesan Dakwah, Kisah, Analisis Semiotika

\section{Pendahuluan}

Islam merupakan agama yang diwahyukan Allah Swt melalui Rasul-Nya. Islam bersifat syumul atau menyeluruh, ajaran lengkap dan sempurna mengatur tata cara kehidupan umat manusia. Ini berarti, Islam diyakini dapat menyapa berbagai problema kehidupan. 
Kehadiran Nabi Muhammad Saw sebagai Rasul dilambangkan jadi kerangka pembebasan kesejahteraan dan kedamaian manusia selaku penghuni bumi melalui risalah yang dibawanya, yakni senantiasa melakukan kegiatan dakwah ke tiap penjuru bumi.

Dakwah merupakan usaha mengajak pada yang ma'ruf (kebaikan) dan melarang pada yang munkar (keburukan). Dakwah juga mempunyai makna sebagai aktivitas yang berfungsi mentransformasikan nilai-nilai Islam sebagai doktrin (ajaran) menjadi kenyataan tata masyarakat dan peradabannya yang mendasarkan pada pandangan dunia Islam yang bersumber pada Alquran dan As-Sunnah. (Amin, 2013, p. 17)

Menurut Munir-Wahyu, ada 6 elemen yang harus diperhatikan dalam kegiatan dakwah ini, yaitu $D a$ 'i (subjek dakwah/komunikator), mad'u (objek dakwah/komunikan), metode dakwah/cara berdakwah, media dakwah, serta materi dakwah (maddah adDakwah/message) dan efek dakwah (Atsar Dakwah). (MunirM, 2009, pp. 21-35)

Menurut hemat penulis, keenam elemen tersebut sangat mempengaruhi kesuksesan dalam berdakwah dan kelimanya mempunyai korelasi antara satu dengan yang lainnya. Abu Nawas dalam kisahnya yang disusun oleh Nur Sutan Iskandar pada tahun 1922 mengimplementasikan keenam elemen itu. Kisah terjemahan dari salah satu kisah atau hikayat Alfu Lailah Wa Lailah (dalam bahasa inggris disebut dengan The Arabian Nights atau The Thousand and One Nights) kepunyaan Koninklijk Bataviaasch Genootschap (sekarang bernama Yayasan Lembaga Kebudayaan Indonesia) untuk mengisi ruang cerita majalah Seri Pustaka. (Nur Sutan Iskandar, 2009, p. 7)

Kisah 1001 malam ini menceritakan seorang Parsi bernama Abu Nawas yang cerdik dan fasih dalam berbicara. Ia mampu memecahkan berbagai persoalan yang dihadapi, baik masalah sosial, politik, bahkan keagamaan dengan stylenya yang nyeleneh.

Abu Nawas adalah seorang sufi berdarah Parsi yang bergelut dalam bidang sastra Arab Klasik, yang digambarkan sebagai sosok yang bijaksana dan humoris. Tetapi dibalik itu, banyak yang mengganggap bahwa Abu Nawas adalah tokoh fiktif yang sengaja dibuat saat kerajaan Harun ar-Rasyid. Hal ini dikatakan fiktif karena banyak cerita yang diadopsi dari luar menjadi Kisah Abu Nawas yang tidak masuk akal dan menyakiti orang timur (Makalah, n.d.). Namun, Sam Abede Pareno menuturkan bahwa Abu Nawas ialah sosok manusia yang nyata meskipun kisahnya tidak bebas dari opini para penutur lelakon lakilaki ini. (Abede Pareno, 2013, p. 67)

Walau sering dianggap kisah Abu Nawas diciptakan hanya untuk menghibur masyarakat, khususnya anak-anak kecil, dengan guyonan atau humor yang disajikan tanpa ada keistimewaan di dalamnya, tapi bila ditelaah kisah Abu Nawas ini mempunyai pesan dakwah yang berdampak pada kehidupan seseorang, baik itu dalam segi penguatan akidah, pengamalan syari'ah atau perbaikan akhlak.

Kondisi kehidupan bangsa Indonesia masih menjadi sarat dengan tindak kriminal, kecurangan, korupsi dan kebobrokan moral lainnya. Perselisihan antar-etnis, ras dan agama yang menyebabkan kematian masih sering terjadi. Misalnya kasus rasisme pada Mahasiswa Papua di Surabaya dan Malang hingga mengakibatkan aksi demo yang anarkis di Manokwari hingga Jayapura.(Arnani, 2019) Demikian pula kasus pembunuhan, bunuh diri, narkoba dan kriminalitas lainnya. Seperti kasus pembunuhan seorang ayah oleh anak tirinya karena tidak tahan melihat ibunya disiksa dan adiknya diperkosa (Lusiana, 2020). Belum lagi kenakalan remaja/pelajar, seperti miras, hamil di luar nikah, dan kekerasan (bullying).

Menurut penulis, kondisi tersebut disebabkan karena lemahnya berakidah dan lalai dalam bersyariah, sehingga efek yang dimunculkan cenderung pada akhlak yang 
tercela. Kasus persoalan ini bisa terjawab melalui pesan dakwah yang terkandung dalam kisah Abu Nawas ini.

Dalam memudahkan penulis memahami pesan dakwah dalam kisah Abu Nawas tersebut, maka penulis menggunakan metode pisau analisis semiotika. Semiotika berarti ilmu mengenai tanda-tanda. Melalui analisis semiotika inilah, penulis akan memaparkan makna menurut tanda-tanda yang muncul dalam kisah Abu Nawas tersebut. Adapun analisis yang akan penulis gunakan dalam penelitian ini adalah analisis semiotika menurut Charles Sanders Peirce.

\section{Metode penelitian}

Sebagai karya ilmiah, setiap pembahasan menggunakan metode untuk menganalisa dan mendeskripsikan suatu penelitian. Metode berfungsi sebagai landasan dalam mengelaborasi suatu penelitian. Penelitian berasal dari terjemahan bahasa Inggris yakni research yang berarti re (mengulang) dan search (pencarian, penelitian dan penyelidikan), maka yang dimaksud dengan penelitian atau research ialah melakukan pencarian suatu masalah tertentu dengan sistematis lalu diolah, dianalisa, disimpulkan dan dicarikan solusinya. (Bachtiar, 1999, p. 1)

Metode penelitian merupakan cara ilmiah untuk mendapatkan data yang objektif, valid, dan kredibel sehingga dapat digunakan untuk memahami, memecahkan dan mengantisipasi penelitian dalam bidang tertentu.

Penelitian pada skripsi ini menggunakan metode Analisis Isi (content analysis) yang digunakan untuk memperoleh keterangan dari komunikasi yang disampaikan dalam bentuk lambang yang terdokumentasi atau didokumentasikan. Analisis isi ini juga dapat memperoleh pemahaman terhadap berbagai isi pesan komunikasi yang disampaikan oleh media massa atau sumber lain secara objektif, sistematis dan relevan. (Zed, 2004)

Di sini peneliti bermaksud mengidentifikasi isi pesan dakwah dalam kisah Abu Nawas melalui pisau analisis semiotika Charles Sanders Peirce.

\section{Hasil dan Pembahasan}

\section{Analisis Semiotika Charles Sanders Peirce}

Semiotika merupakan studi yang mempelajari makna atau arti dari suatu tanda atau makna. Untuk memahami makna dalam kisah Abu Nawas ini, penulis menggunakan analisis semiotika menurut Charles Sanders Peirce.

Semiotika Charles Sanders Peirce dikenal dengan model triadic dan konsep trikotominya yang terdiri atas berikut ini (Sobur, n.d., pp. 41-43) :

1. Representamen atau ground adalah bentuk yang diterima oleh tanda atau berfungsi sebagai tanda.

2. Object merupakan sesuatu yang merujuk pada tanda.

3. Interpretan adalah tanda yang ada dalam benak seseorang tentang objek yang dirujuk sebuah tanda.

Berikut merupakan gambar segitiga makna Charles Sanders Peirce. 


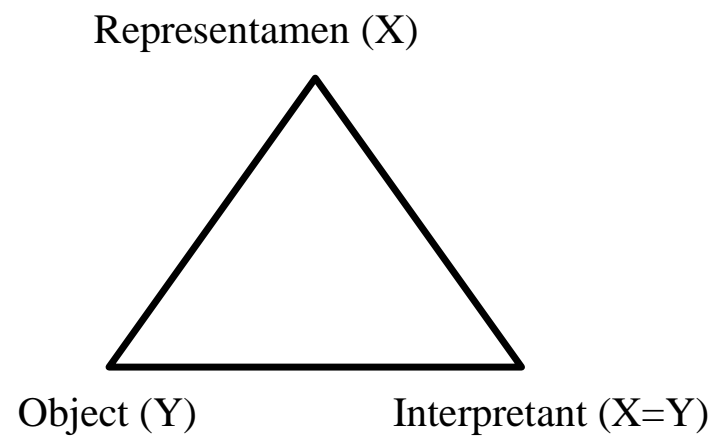

Gambar 2.1: Model Segitiga Makna Peirce (Marcel Danesi) (Danesi, 2011, p. 33)

1. Pesan Dakwah Konsep Akidah

Akidah merupakan suatu keyakinan.(Yunahar, 2011, p. 1) Maksudnya mencakup I'tiqad bathiniyyah yakni mencakup masalah-masalah rukun Iman.

Pesan Dakwah konsep akidah dalam Kisah Abu Nawas ini ialah mengenai iman kepada Allah. Iman kepada Allah artinya percaya dan yakin adanya Allah Swt karena dzatnya sendiri (wajib al-wujud li-Dzati), tunggal dan esa (Ibrahim, 1998, p. 133). Manusia wajib menanamkan dalam dirinya untuk beriman kepada Allah Swt. (Q.s AnNisa ayat 136)

Dalam kisah Abu Nawas yang berjudul Abu Nawas Menjadi Raja Sesaat Saja, ada penggalan begini:

Jawab Abu Nawas, "Bintang di langit pun demikian juga, Tuanku. Siapakah yang dapat menghitungnya, melainkan Allah jua yang tahu akan banyaknya itu. "(Nur Sultan Iskandar, n.d.)

Representamen yang muncul pada penggalan kisah tersebut ialah pertanyaan seputar keadaan bintang di langit. Adapun yang menjadi objek ialah ketika Abu Nawas menjawab bahwa hanya Allah saja yang tahu. Interpretant yang didapat, Abu Nawas meyakini atau mengimani bahwa hanya Allah saja yang Maha Mengetahui segala apa yang ada di langit dan bumi. Artinya, Abu Nawas telah mengimani Asma Allah yaitu Al'Alim (Maha Mengetahui) dan mengamalkan point Iman Kepada Allah Swt.

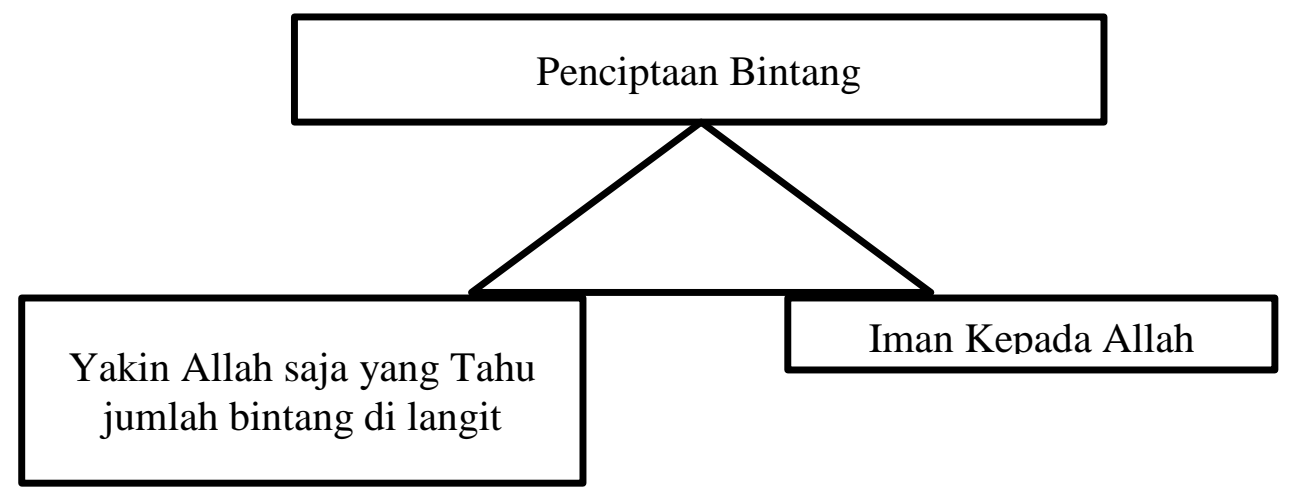

\section{Pesan Dakwah Konsep Syariah}

Syariah adalah peraturan yang diciptakan Allah supaya manusia berpegang teguh dalam hubunganya terhadap Allah (Ibadah) dan hubungannya dengan manusia (mu'amalah). Pesan dakwah konsep syariah dalam 
a. Shalat

Shalat merupakan amalan mengagungkan Allah (takbir) dan diakhiri dengan salam(Sabiq, 1997, p. 78). Shalat merupakan salah satu rukun islam yang tidak boleh ditinggalkan. Karena sholat itu hukumnya wajib bagi orang-orang beriman, (Q.s AlBaqarah [2]: 43)

Ada pesan dakwah mengenai konsep syariah dalam kisah Abu Nawas ini, tercantum dalam judul Seekor Harimau Yang Berjanggut.

Baginda menginginkan Abu Nawas menangkap harimau berjanggut.

"Dicari-carinya akal akan mencelakakan daku, supaya lepas dendamnya, ya, aku pun harus hati-hati dan..." kata Abu Nawas dalam hati. Seta sampai, maka dipanggilnya empat orang tukang kayu, lalu disuruhnya membuat kandang harimau. Di dalam tiga hari selesailah kandang itu. Kemudian Abu Nawas pun masuk ke dalam rumahnya, diambilnya sehelai tikar sembahyang, akan dibawanya ke langgar. Ia berkata kepada istrinya, "Hai Adinda, jika datang seseorang yang berjanggut ke rumah kita, Adinda persilahkan duduk serta bercakap-cakaplah dengan dia. Dan apabila Adinda dengar kakanda mengetuk pintu, Adinda suruh dia masuk ke dalam kandang itu!"

Representamen dari penggalan kisah di atas ialah sehelai tikar sembahyang. Sebagaimana sehelai tikar sembahyang atau sejadah itu sebagai alat atau tanda alat yang suka dipakai untuk ibadah sholat. Maka muncul objek, yaitu sholat itu sendiri. Interpretantnya Abu Nawas memberi pesan kepada para pembaca untuk senantiasa mengerjakan sholat bagaimana pun keadaannya.

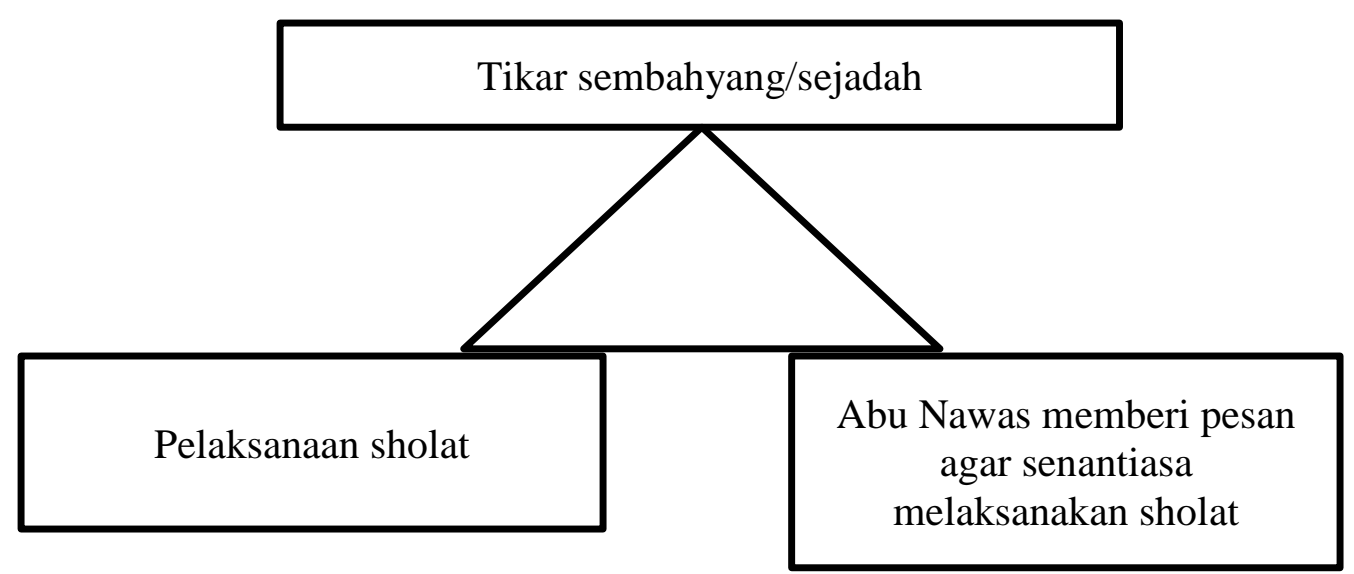

b. Pengurusan Jenazah

Manusia sebagai makhluk sebaik-baik ciptaan Allah, maka Islam sangat menghargai dan menghormati orang muslim yang meninggal dunia. Oleh sebab itu, menjelang menghadapi kekariban Allah Swt, orang yang meninggal dunia mendapatkan perhatian khusus (Sabiq, 1981, p. 78). Dalam ketentuan hukum Islam, pengurusan jenazah itu hukumnya fardhu kifayah yakni kewajiban yang bersifat kolektif. Dan wajib bagi orang-orang yang masih hidup menyelenggarakan empat perkara, yaitu memandikan, mengkafani, menshalatkan dan menguburkan.

Pada kisah Abu Nawas yang berjudul Abu Nawas dan Bapaknya, ada pesan dakwah tentang syariah. Begini penggalan kisahnya sebagai berikut.

.....Beberapa hari kemudian bapak Abu Nawas sungguhlah kembali ke rahmatullah ta'ala. Kapan dan nisan sudah dibeli oleh Abu Nawas. Maka ia pun 
pergilah masuk ke dalam istana menghadap Sultan Harunurrasyid akan memberitahukan kalau bapaknya sudah mati. Demi didengar amirul mukminin Sultan Harunurrasyid hal Abu Nawas datang itu, maka sabda Baginda, "Hai, Abu Nawas, pergilah engkau kuburkan bapakmu seperti adat Maulana Kadi juga."

Abu Nawas pun pergilah menguburkan bapaknya, seperti kadi perbuatannya....(Nur Sultan Iskandar, n.d., p. 14)

Representamen pada kalimat Bapak Abu Nawas kembali ke rahmatullah yaitu hamba yang telah wafat. Lalu objeknya ialah ketika ayahnya meninggal, Abu Nawas segera membeli kafan dan nisan kemudian menguburkannya, yakni adanya usaha untuk mengurusi jenazah. Maka interpretannya ialah Abu Nawas memberi pesan tentang kepengurusan orang yang wafat (kepengurusan jenazah).

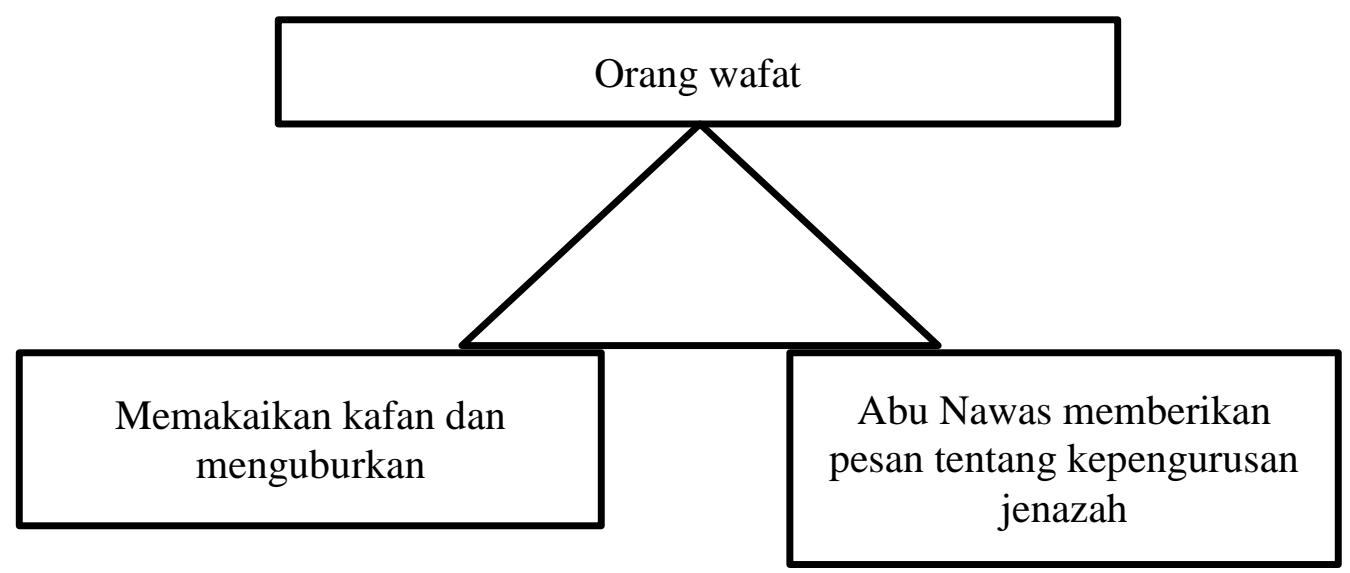

3. Pesan Dakwah Konsep Akhlak

Akhlak merupakan implementasi dari akidah dan syariah. Biasanya akhlak akan muncul secara spontan bilamana diperlukan. Penulis menemukan ada 2 pesan dakwah akhlak yang terkandung dalam kisah Abu Nawas ini. Yaitu pesan dakwah akhlak terhadap Allah dan terhadap sesama.

a. Pesan Dakwah Akhlak Terhadap Allah

Salah satu pengamalan dari akhlak terhadap Allah Swt ialah dengan melakukan Ibadah hanya untuk Allah Swt. Ibadah berarti penghambaan diri, pernyataan bakti terhadap Allah yang didasari oleh agama. Tugas utama manusia sebagai khalifah di bumi ini ialah untuk beribadah pada Allah Swt. (Q.s Adz-Dzariyat [51]: 56)

Di antara akhlak terhadap Allah ialah dzikir kepada Allah Swt dan berdo'a.

1. Dzikir kepada Allah

Dzikir berarti kegiatan yang senantiasa mengingat Allah Swt dalam beragam macam aktivitas, baik itu secara lisan, hati maupun perbuatan. Dzun Nuun al-Mishry menegaskan pula orang yang berdzikir pada Allah Swt, maka ia akan lupa segala sesuatu selain dzikirnya. Allah akan melindunginya dari segala sesuatu, dan ia akan diberi ganti dari segala sesuatu.

Janji Allah bagi hamba yang senantiasa mengingatnya ialah dirinya akan merasa beruntung. (Q.s Al-Jumu'ah [62]: 10) 
Dzikir bisa dilakukan dengan berbagai cara. Bisa dengan beristighfar atau

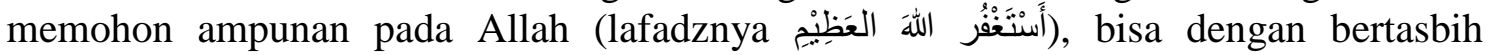
(lafadznya سُبْحَانَ اللهِ (Alhamdulillah), tahmid bertakbir (lafadz: Allahu Akbar) atau bertahlil (Laa ilaa ha illallah)

Pada pembahasan kali ini, penulis menemukan pesan dakwah dalam kisah Abu Nawas yang berkenaan dengan pengamalan dzikir kepada Allah Swt. antara lain ialah dengan bertahmid. Tercantum dalam kisah yang berjudul Seekor Harimau yang Berjanggut (Nur Sutan Iskandar, 2009, p. 114). berikut.

Adapun percakapan yang mewakili konsep dzikir kepada Allah ialah sebagai

Setelah Abu Nawas menceritakan dia dan istrinya bermasalah dalam keluarga....Pikir penghulu itu di dalam hatinya, "baiklah Abu Nawas ini ku biar tinggal di sini dan aku pergi ke rumah bininya itu. Aku telah lama menaruh berahi kepada perempuan yang cantik itu, Sekarang cita-cita itu dapat aku..." Lalu katanya pada Abu Nawas: "Hai Abu Nawas! Sukakakah engaku perselisihan itu terselesaikan? Tunggulah di sini, aku pergi sebentar menemui istrimu itu!"

Jawab Abu Nawas, "Alhamdulillah, hamba mengucap terima kasih sebanyakbanyaknya akan kesucian hati Tuan hamba itu.” (Nur Sultan Iskandar, n.d., p. 115)

Representamen dalam kisah ini ialah ada pada kata Alhamdulillah. Alhamdulillah atau kalimat tahmid ini merupakan pengungkapan bentuk syukur atas apa yang telah diterima oleh Abu Nawas. Bisa dilihat pada penggalan kata setelahnya, terdapat kata terima kasih. Bila dilihat makna dibalik itu, ada suatu bentuk kesyukuran atas nikmat yang Allah beri. Artinya, Abu Nawas mengingat bahwa nikmat yang ia terima datangnya dari Allah. Ini berarti syukur adalah objek dari represemtamen kalimat Alhamdulillah.

Setelah ditemukan objek yang muncul, yakni kesyukuran, selanjutnya ditemukan sebuah interpretant atau makna. yang muncul ialah dzikir pada Allah. Sebagaimana yang diungkapkan pada halaman sebelumnya bahwa salah satu ciri dzikir pada Allah ialah dengan mengucapkan kalimat-kalimat baik seperti kalimat tahmid (Alhamdulillah).

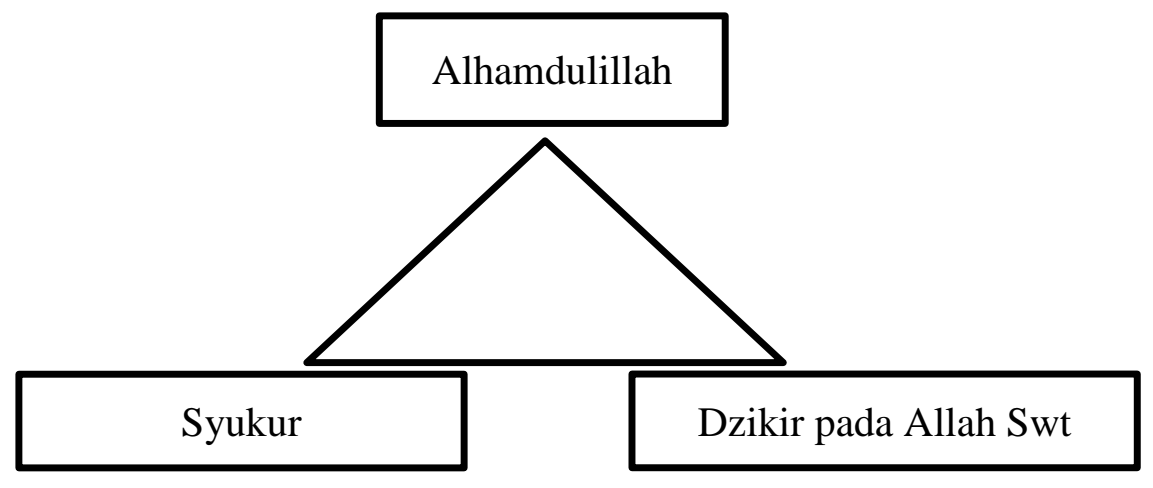

2. Berdo'a

Berdoa merupakan memohon pertolongan kepada Allah Swt sebagai Tuhan pemilik alam semesta ini disertai dengan kerendahan hati dan berserah diri untuk memperoleh suatu kebaikan dan kemashlahatan. Allah sangat menyukai hamba yang senantiasa mendekat padanya dan berdo'a padanya. (Q.s Al-Baqarah [2]: 186)

Janji Allah dalam firmanNya tersebut ialah Allah akan mengabulkan do'a atau permohonan setiap hamba yang memohon. Dan mengabulkan permintaan orang yang berdo'a ini sifatnya umum. Dalam Majmu' Fatawa (HR. Abu Daud, No. 2511, Ibnu 
Hibban, No. 808, Ahmad, 2:302., n.d., p. 223). dikatakan Allah mengabulkan do'a orang yang terjepit masalah dan do'a orang yang didzolimi, meskipun orang kafir sekali pun.

Karena Allah sangat menyukai ketika hambaNya memohon pertolongan padaNya, maka Abu Nawas pun dalam kisahnya yang berjudul Orang Miskin Dengan KolamYang Dingin Airnya (Nur Sultan Iskandar, n.d., pp. 74-76).

Singkat cerita, di negeri Baghdad ada seorang saudagar kaya yang mempunyai kolam yang sangat dingin airnya. Saudagar kaya ini melakukan sayembara 'Barangsiapa yang tahan berendam di kolam itu satu malam, akan kuberi uang sepuluh ringgit'.

Terdengarlah kabar tersebut hingga ke si Miskin yang sangat membutuhkan uang. Si Miskin pun meminta izin pada anak dan istrinya untuk ikut sayembara tersebut. Sesudah diizinkan, bergegaslah si miskin ke rumah saudagar kaya itu dan berendam di kolam itu semalaman. Namun naas, ketika si miskin berhasil berendam selama satu malam, saudagar kaya tersebut enggan memberikan uang sepuluh ringgit itu, "Mana boleh aku beri, sebab anak engkau menjadikan api di tepi kolam itu. Niscaya panas api itu dapat menolong engkau!"

\section{b. Pesan Dakwah Akhlak Terhadap Manusia}

Selain hubungan vertikal (hubungan pada Allah), Islam juga memperhatikan hubungan horizontal (hubungan manusia dengan manusia, baik terhadap dirinya sendiri atau terhadap sesama). Hal ini menjadi bukti bahwa Allah sangat memperhatikan hakhak manusia, seperti tidak merugikan dirinya atau orang lain.

1) Berbakti pada orangtua

Akhlak terhadap orangtua maksudnya berbudi baik pada orangtua. Orangtua yang dimaksud penulis di sini ialah ayah dan/atau ibu seorang anak yang memiliki hubungan biologis dan sosial.

Menghormati orangtua sangat ditekankan dalam Islam. (Q.s Al-Isra [17]: 23-24) Berbakti dan taat pada orangtua terbatas pada perkara yang ma'ruf. Adapun apabila orangtua menyuruh pada kekafiran, maka tidak boleh taat kepadanya. Allah Swt berfirman dalam (Q.s Al-Ankabut [29]: 8)

Bentuk berbakti pada orangtua itu bisa bergaul, berkata dengan cara yang baik, berperilaku rendah hati dan senantiasa mendo'akannya.

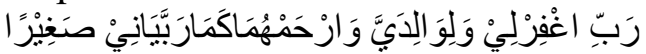

Artinya: Ya Tuhan, ampunilah aku dan kedua orang tuaku sebagaimana mereka menyayangiku di waktu kecil.

Apabila kedua orangtua meninggal, maka yang wajib dilakukan ialah mendo'akan keduanya dan menyambungkan silaturahim pada orang yang keduanya juga pernah menyambungnya.(Jawas, 2006)

Pada pembahasan kali ini, penulis menemukan pesan dakwah dalam kisah Abu Nawas yang berkenaan dengan berbakti pada orangtua, yakni dalam judul Abu Nawas dan Bapaknya (Nur Sultan Iskandar, n.d., pp. 13-14).

Syahdan penghulu (kadi) itu pun hampirlah akan kembali ke rahmatullah taala. Maka disuruhnya panggil anaknya yang bernama Abu Nawas itu. Anak itu pun datanglah dengan segera mendapatkan bapaknya itu.

Kata bapaknya kepada Abu Nawas, "Hai Anakku! Adapu aku ini hampirlah akan meninggalkan dunia. Ciumlah olehmu telingaku kanan dan kiri."

Setelah itu Abu Nawas pun segera mencium telinga bapaknya. Adapun bau telinga bapaknya yang sebelah kanan itu terlalu harum dan yang sebelah kiri sangat 
busuk baunya. Setelah sudah, maka kata bapaknya itu kepadanya, "Hai Anakku, Abu Nawas, dapatkah engkau mencium baunya itu?"

Data berupa tanda (Representamen) yang muncul pada penggalan cerita tersebut ialah sebagai berikut.

Ketika bapaknya Abu Nawas memerintahkan pada Abu Nawas untuk segera mendekati dan mencium telinganya, maka respon dari Abu Nawas adalah sebagai berikut.

"Anak itu pun datanglah dengan segera mendapatkan bapaknya itu."

"Setelah itu Abu Nawas pun segera mencium telinga bapaknya"

Kedua kalimat tersebut merupakan representamen dari pernyataan sebagai anak. Anak di kalimat tersebut diungkapkan sebagai kata ganti orang ketiga yang berfungsi sebagai subjek. Anak yang dimaksud di sini ialah Abu Nawas.

Setelah kata anak/Abu Nawas, ada kata datanglah dengan segera mendapatkan bapaknya dan segera mencium bapaknya. Bila dilihat makna dibalik itu, ada suatu ketaatan atau kepatuhan terhadap bapaknya. Yang mana, kepatuhan terhadap bapaknya bisa menjadi objek dari representamen (si anak atau abu nawas).

Setelah ditemukan objek yang muncul ialah kepatuhan terhadap bapak, selanjutnya ditemukan sebuah interpretant atau makna. Berdasarkan pada kedua kalimat tersebut, interpretant yang muncul ialah berbakti pada orangtua untuk mencapai keridhoan. Baik itu keridhoan dari orangtua maupun keridhoan Allah Swt.

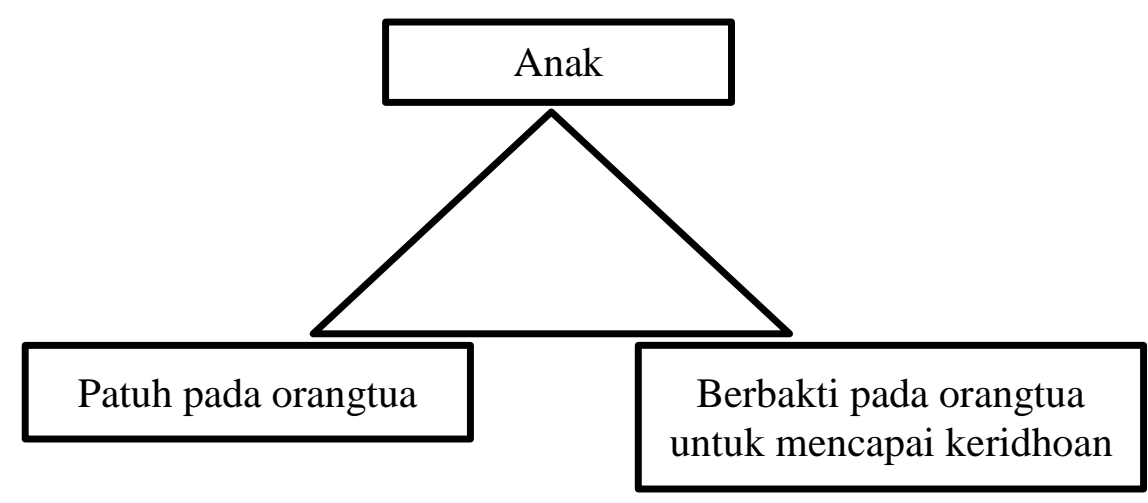

2) Bersikap jujur

Jujur merupakan sifat yang melekat dalam diri seseorang dan merupakan hal penting yang harus dilakukan dalam kehidupan sehari-hari. Menurut Tabrani, jujur dalam bahasa arab merupakan terjemahan dari kata shiddiq yang artinya benar, dapat dipercaya.

Seseorang yang berlaku jujur disebut shiddiq (orang yang senantiasa jujur). Kejujuran itu perhiasan bagi orang yang berbudi mulia dan orang yang berilmu. Jujur dapat mengantarkan pada kebaikan dan kebaikan akan menyampaikan pada surga.

Sabda Nabi Saw:

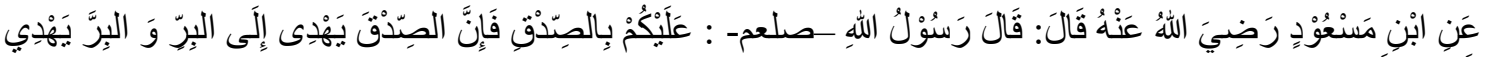

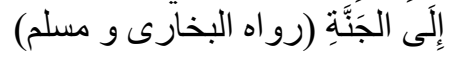

Artinya: Dari Abdullah bin Mas'ud ia berkata: Rasulullah Saw bersabda: "Hendaknya kamu selalu jujur karena kejujuran itu akan membawa kepada kebaikan dan kebaikan itu akan membawa ke dalam surga." (HR Bukhari dan Muslim)

Kebalikan sifat jujur adalah dusta. Dusta mengantarkan pada perilaku menyimpang (dzalim) dan perilaku menyimpang mengantarkan kepada neraka. Orang senantiasa berdusta akan dicap sebagai pendusta. 
Pada pembahasan kali ini, penulis menemukan pesan dakwah dalam kisah Abu Nawas yang berkenaan dengan senantiasa berlaku jujur, yakni dalam judul Abu Nawas dan Bapaknya (Nur Sultan Iskandar, n.d., pp. 16-17).

Setelah bapaknya wafat, Abu Nawas berpura-pura gila untuk mencegah pengangkatan dirinya menjadi kadi oleh raja Harun Ar-Rasyid. Abu Nawas membuat jengkel raja sehingga dirinya dipukul oleh sahayanya raja sebanyak 25 kali. Karena Abu Nawas mendapati perjanjian dengan penjaga istana apapun yang dilakukan oleh raja, maka penjaga istana pun harus terbagi juga. Abu Nawas telah dipukul, maka pihak penjaga istana raja pun dipukuli Abu Nawas pula sebagai bentuk penyamarataan atas apa yang raja beri. Hingga suatu ketika, penjaga istana pun mengadu pada raja dan Abu Nawas kembali dipanggil ke istana untuk mendapat keterangan sebenarnya. Abu Nawas pun menjelaskan perjanjian yang mereka buat

Sabda baginda kepada penunggu pintu kota, "Hai penunggu kota! Betulkah engkau ada berjanji padanya demikian?”

Sahut orang yang menunggu pintu kota itu, "Ya Tuanku, betul hamba ada berjanji kepadanya akan demikian itu."

Sabda Harunarrasyid, "Jika demikian, Abu Nawas tiada salah sama sekali."

Data berupa tanda (Representamen) yang muncul pada penggalan cerita tersebut ialah ketika penunggu kota mengakui kesalahannya. "Betul hamba ada beranji kepadanya demikian".

Pernyataan betul ini bisa menjadi kalimat kesepakatan dan kalimat pembenaran atas apa yang ditanyakan atau diucapkan oleh raja pada penunggu kota. Ini berarti adanya pengakuan kesalahan yang bisa dijadikan suatu tanda (representamen). Dilanjutkan pada kalimat hamba ada berjanji kepadanya demikian. Ini bisa menjadi objek dari representasi kalimat betul, yang menyatakan hal yang sebenarnya atau berterus-terang atas kesalahan yang dibuatnya. Ini berarti, pesan dakwah yang ingin disampaikan penulis kisah Abu Nawas pada pembaca ialah agar senantiasa berlaku jujur pada sesama. Tetapi, sebenarnya kejujuran itu bukan hanya diperuntukkan pada sesama saja. Akan tetapi, kejujuran pula hendaklah ditanamkan dalam diri sendiri.

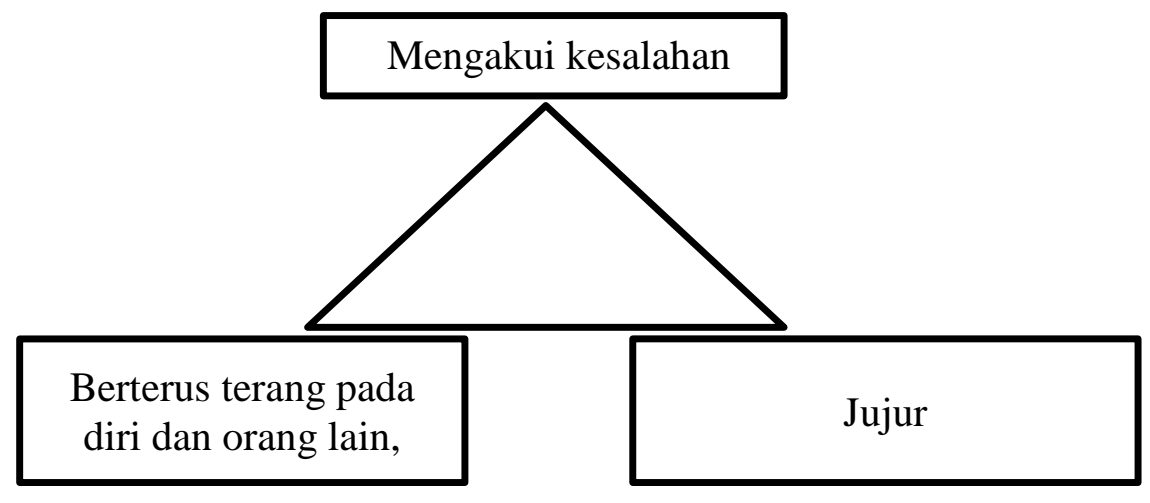

\section{Kesimpulan}

Setelah melakukan analisis dan pembahasan pada bab-bab terdahulu, maka penulis mengambil kesimpulan bahwa pesan dakwah dalam kisah Abu Nawas ada yang berkaitan dengan akidah, syariah dan akhlak.

Pesan dakwah yang berkaitan dengan akidah ialah iman kepada Allah Swt.Syariah ialah shalat dan kepengurusan jenazah. Adapun yang berkaitan dengan akhlak ialah akhlak kepada Allah dan akhlak terhadap manusia. 


\section{Bibliografi}

Abede Pareno, Sam. (2013). Komunikasi ala Punokawan \& Abu Nawas. Surabaya: Henk Publica.

Amin, Samsul Munir. (2013). Ilmu Dakwah.

Arnani, Melani. (2019). Kerusuhan di Papua, Apa yang Terjadi di Manokwari hingga Jayapura?, Kompas.com/tren/red/2019/08/29/183000065/kerusuhan-dipapua-apayang-terjadi-di-manokwari-hingga-jayapura.

Bachtiar, Wardi. (1999). Metode Penelitian Dakwah.

Danesi, Marcel. (2011). Pesa, Tanda, Dan Makna-Makna.

HR. Abu Daud, No. 2511, Ibnu Hibban, No. 808, Ahmad, 2:302. (n.d.).

Ibrahim, Habib Zain bin. (1998). Hidayatuth Thalibin Fii Bayan Muhimmatid-dien terj. Afif Muhammad (Mengenal Mudah Rukun Islam, Rukun Iman, Rukun Ikhsan secara Terpadu.

Iskandar, Nur Sultan. (n.d.). Abu Nawas.

Iskandar, Nur Sutan. (2009). Abu Nawas, Cet. Ke-33.

Jawas, Yazid bin Abdul Qadir. (2006). Bingkisan Istimewa Menuju Keluarga Sakinah. Cet. II, Bogor: Pustaka At-Taqwa.

Lusiana, Nanda. (2020). Anak Bunuh Ayah Tiri karena Ibunya Dianiaya dan Adik Diperkosa: Tak Masuk Pasal Pembunuhan Berencana, https://www.tribunnews.com/regional/2020/08/02/anak-bunuh-ayah-tiri-karenaibunya-dianiaya-adik-diperkosa-tak-masuk-pasal-pembunuhan-berencana.

Makalah, Referensi. (n.d.). Kisah Abu nawas: Sang Penggeli Hati https://www.referensimakalah.com/2010/12/kisah-abunawas-sang-penggelihati_6976.

MunirM, Wahyu Ilahi. (2009). Manajemen Dakwah Cet. Ke. 2.

Sabiq, Sayyid. (1981). Fiqih Sunnah 4 Mazhab Terjemah, cet ke-3.

Sabiq, Sayyid. (1997). Fiqh As-Sunnah.

Sobur, Alex. (n.d.). Semiotika Komuniasi.

Yunahar, Ilyas. (2011). Kuliah Aqidah Islam. Yogyakarta: LPPI (Lembaga Pengkajian Dan Pengamalan Islam.

Zed, Mestika. (2004). Metode peneletian kepustakaan. Yayasan Obor Indonesia. 